\title{
PENDEKATAN EPISTEMOLOGI DAN INTERSUBJEKTIF ATAS HADIS-HADIS NIKAH MUT'AH
}

\author{
Muhammad Nashrul Haqqi \\ Universitas Islam Nahdlatul Ulama Jepara \\ e-mail: nazhroul@yahoo.com
}

\begin{abstract}
This article offers an alternative perspective at the difference views in the Sunni and Shi'ite hadiths for Mut'ah marriage. Related to the differences both treat and apply that these hadits universally believed to be one of the fundamental sources of Islam. Eventhough, both Sunny and Shilite agree to put hadits as a second source of doctrine, but they often actually produce a different formulation of the law and contradictory. The difference of theological view is a fundamental problem that implies on their thought dealing with being accepted or rejected for hadits transmition of Mut'ah merriage. Intersubjectivity approach has roled to positionize these groups as an objective opinion, subjective as well. Both objectivities are located on the seriousness of their respective efforts to obtain the authenticity of the hadith, in which expectations will be both objectivity when hadith of mut'ah marriages take placed purely as historical information. In this position, the awareness together to build the Islamic civilization in the theological differences, are values that should be a priority.
\end{abstract}

[]

Tulisan ini menawarkan suatu perspektif alternatif dalam memandang perbedaan Sunni dan Syi'ah dalam memandang hadits-hadits nikah Mutah, terkait dengan perbedaan di antara keduanya memperlakukan dan menerapkan Hadis yang secara universal diyakini sebagai salah satu sumber fundamental ajaran Islam. Perspektif tersebut menjadi penting, karena meskipun sepakat menempatkan Hadis sebagai sumber ajaran kedua, keduanya acapkali justru menghasilkan rumusan hukum yang berbeda, bahkan kontradiktif. Perbedaan posisi teologis merupakan persoalan mendasar yang pada akhirnya meluas dan berimplikasi pada penilaian keduanya terkait dengan diterima atau ditolaknya sebuah transmisi Hadis nikah mutah. Intersubjektivitas berperan memposisikan keduanya sebagai pendapat yang objektif, sekaligus subjektif. Objektivitas keduanya terletak pada kesungguhan upaya masing-masing untuk memperoleh otentisitas sebuah Hadis, di mana ekspektasi objektivitas keduanya akan menjadi subjektif ketika Hadis-hadis nikah mut'ah itu murni diletakkan sebagai informasi sejarah. Pada posisi semacam ini, kesadaran bersama untuk membangun peradaban Islam dalam perbedaan teologis tersebut adalah nilai yang seharusnya lebih diutamakan.

Keywords: epistemologi, hadis nikah mut'ah, intersubjektivitas, Sunni-Syi'ah

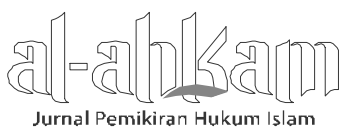

Volume 24, Nomor 2, Oktober 2014 


\section{Pendahuluan}

Secara sederhana, dalam berbagai varian penyebutannya, Hadis adalah potret sejarah yang merekam perjalanan hidup Nabi Muhammad SAW, 14 abad yang lalu. Sebagai pembawa ajaran, posisi Nabi begitu penting, sehingga segala sesuatu yang terkait dengan beliau menjadi urgent untuk diketahui, dipahami dan dijalankan oleh komunitas di sekelilingnya. Dalam perjalanannya, segala bentuk informasi tentang Nabi tersebut disepakati menjadi entitas yang terformatisasi sebagai sumber ajaran kedua, di samping al-Qur'an sebagai wahyu atau entitas ketuhanan (ilähi/divine) yang menduduki posisi tertinggi. Tidak hanya demi kepentingan perumusan hukum (fiqh), kedua entitas tersebut (al-Qur'an dan Hadis) sejatinya adalah sumber atau epistemologi berbagai wilayah ajaran Islam, meliputi teologi, etika, moralitas dan sebagainya, sebagai petunjuk bagi manusia dalam beribadah dan berkehidupan.

Sebagai informasi sejarah yang penting bagi otentisitas sekaligus keberlangsungan agama yang berkembang tidak hanya di wilayah Arab, namun juga meluas ke berbagai penjuru dunia dari masa ke masa. Berbagai informasi itu kemudian menjadi niscaya untuk tidak hanya dihafalkan, namun juga untuk diseleksi dan didokumentasikan. Baik melalui otoritas kelompok maupun karena berbagai motif kepentingan tertentu. Kaidah-kaidah penilaian yang berupaya melihat apakah informasi itu benar-benar disampaikan, dilakukan dan terjadi pada Nabi SAW, berikut pemahaman yang objektif jika informasi-informasi itu sulit dipahami atau bahkan saling kontradiktif juga dibangun dan berkembang dari waktu ke waktu. Tidak hanya itu, kontekstualisasi atau ekspansi pemaknaan Hadis juga terus dikembangkan, mengingat kondisi dan lingkungan Nabi yang jelas berbeda dengan kondisi masyarakat Muslim di tempat lain, utamanya pada masa sekarang.

Salah satu dimensi yang menarik dalam kajian Hadis adalah fenomena munculnya banyak faksi dalam historisitas perjalanan Islam itu sendiri. Hauqola menyebutnya sebagai ideologi internal, ${ }^{1}$ yang beberapa di antaranya masih bertahan hingga saat ini. Lepas dari apakah kemunculan faksi tersebut bermotif politik, teologis, atau perbedaan pemikiran jurisdis, divergensi tersebut nampak

\footnotetext{
${ }^{1}$ Nur Kholis Hauqola, "Otentitas Sunnah dan Kedudukannya dalam Legislasi Hukum Islam” dalam Al-Ahkam; Jurnal Pemikiran Hukum Islam, Vol.24, No. 1, 2014. h. 54-55. 
seolah telah menjadi ideologi mapan yang sulit untuk disatukan. Dimensi kemapanan ideologi tersebut bahkan telah mengeras dalam bangunan teologi, hukum, dan piranti-piranti di dalamnya, termasuk dalam menempatkan atau memperlakukan epistemologi ajaran. Meskipun keduanya menyepakati al-Qur'an dan Hadis sebagai epistemologi ajaran tertinggi, Sunni dan Syi'ah --mewakili faksi besar yang masih bertahan-- memiliki bangunan teologis yang berbeda, di mana hal itu juga berimplikasi pada rumusan ajaran yang dalam beberapa aspek juga meniscayakan perbedaan.

Dalam konteks saat ini, perbedaan itu seringkali menjadi sumber ketidaknyamanan bagi masing-masing pengikutnya. Terlebih karena perbedaan itu terjadi di internal, atau dalam agama (reine religion glaube / pure religious faith) yang pada dasarnya adalah satu. Perbedaan legalitas praktik keagamaan, seperti nikah mut'ah misalnya, adalah contoh di mana masing-masing pihak ingin menunjukkan bahwa praktik tersebut adalah benar atau justru "keliru" (truth-claim), menurut kaidah-kaidah dan epistemologi hukum yang dikembangkan masing-masing. Efek negatif di dalamnya adalah sikap saling menyalahkan dan merendahkan. Dalam kondisi yang buntu (deadlock) dan tidak ada dialog, perbedaan tersebut bahkan mampu menjadi pemicu terjadinya konflik dan disharmoni.

Untuk menjembatani dilema tersebut, tulisan ini ingin mendeskripsikan epistemologi Hadis dalam tradisi Sunni dan Syi'ah tentang nikah mut'ah, dalam suatu bentuk komparasi. Jauh dari motivasi menghakimi salah satu di antara keduanya sebagai yang benar dan yang lain sebagai yang salah, tulisan ini justru ingin menunjukkan perbedaan konsep Hadis dalam tradisi Sunni dan Syi'ah secara mendalam, sehingga struktur fundamental di antara keduanya dapat terpetakan secara jelas. Tujuan utamanya tidak lain hanya untuk mewacanakan mentalitas pencerahan (al-'aql al-jadīd al-istițlāî̀) yang mengedepankan empati, simpati, perdamaian (perpetual peace) dan sikap saling menghormati dalam hidup berdampingan. Tidak hanya di antara berbagai keyakinan, agama dan teologi, melainkan juga di antara berbagai suku bangsa, ras, etnis, warna kulit dan bahasa dalam menghadapi berbagai problem kontemporer masyarakat multikultural.

Di samping itu, tulisan ini berupaya menempatkan diri pada posisi dan pola intersubjektif sebagaimana diurai dalam poin sebelumnya. Dalam bentuk konvensionalnya, tulisan ini ingin mendeskripsikan jawaban atas pertanyaan-pertanyaan epistemologis terkait dengan perbedaan di antara Sunni dan Syi'ah tentang: 
1) Bagaimana kedua kelompok tersebut memandang atau mendefinisikan Hadis; 2) Bagaimana keduanya memandang kriterium klasifikasi atau pemilahan sebuah Hadis, sehingga Hadis itu dapat diterima dan memiliki legitimasi digunakan sebagai landasan ajaran; serta 3) Bagaimana implikasi yang muncul ketika terdapat perbedaan dalam memandang berikut memperlakukan Hadis nikah mut'ah.

Dalam framework itu, data-data yang diperlukan diperoleh dari literatur Sunni maupun Syi'ah secara berimbang. Deskripsi dan komparasi kedua epistemologi Hadis tersebut, dalam terminologi fenomenologi agama dan integrasinya terhadap keilmuan Islam, merupakan salah satu ikhtiar untuk menemukan substansi di balik perbedaan (eidetic-vision/tabāyun), di samping tuntutan untuk mampu bersifat netral (epoche) dalam menyikapi perbedaan yang nampak pada kulit luarnya.

\section{Konsep Intersubjektif}

Memposisikan diri dalam konstelasi metodologi keilmuan modern, model integrasi keilmuan Hadis konvensional dan filsafat menjadi niscaya dalam kajian ini. Dilihat dari perspektif fenomenologi agama, ${ }^{2}$ beberapa kajian menarik tentang Syi'ah dapat dianalisis dan dipetakan dalam tiga pola, yaitu subjektifis, objektifis dan intersubjektif.

Suatu penelitian Hadis tentang keluarga atau keturunan Nabi ('itrah alnabawiyyah), yang ditengarai menjadi salah satu landasan teologis pendukung Syi'ah untuk mengagungkan ahl al-bayt secara berlebihan, ${ }^{3}$ adalah sebuah contoh di mana dimensi subjektif sebuah penilaian berpotensi terjadi. Dawud Rasyid menilai bahwa Hadis yang ditelitinya memiliki kelemahan pada aspek transmisi, namun menjadi bernilai hasan karena banyak diriwayatkan. Sementara pada aspek konten (matn), dengan mengunggulkan interpretasi Sunni, Rasyid berpandangan bahwa Hadis tersebut harus dipahami dalam konteks bahwa Nabi SAW, meninggalkan al-Qur'an dan keluarganya ('itrah) sebagai panduan, di mana pemahaman atas al-Qur'an dan sunnah akan menjadi lebih otentik melalui eksplanasi lebih lanjut oleh keluarga atau komunitas yang dekat dengan kehidupan Nabi SAW. Berbeda dengan interpretasi Syi'ah yang justru menempatkan keluarga

${ }^{2}$ Amin Abdullah, Islamic Studies di Perguruan Tinggi; Pendekatan Integratif-Interkonektif, (Yogyakarta: Pustaka Pelajar, 2006), h. 210.

3Dawud Rasyid, "Mawqif Ahl 'l-Sunnah wa 'l-Shỉah Nahw al-'Itrah al-Nabawiyyah” dalam Miqot Jurnal Ilmu-ilmu Keislaman, Vol. 37, No. 1, 2013, h. 1-28.

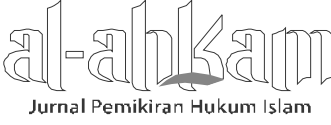


Nabi terbatas pada 'Ali, Fatimah dan keturunannya (holy family) yang berakhir pada konsep imāmah, sebagai satu-satunya golongan yang terbebas dari kesalahan (ma'sūm), serta layak untuk diikuti perintahnya. Penelitian Rasyid tergolong sebagai kajian yang memenuhi standar ilmiah. Namun sisi subjektivitas Rasyid muncul dari sentimen penilaian normatif-insider: dengan hanya mentakhrj beberapa riwayat dalam kitab-kitab kompilasi Sunni, tanpa menyebut kitab-kitab kompilasi Syi'ah. Begitu juga dengan anarki penggunaan kaidah kritik atau penilaian (naqd) Hadis yang menegasikan kaidah ilmu Hadis dalam tradisi Syi'ah. Penelitian Rasyid juga bernuanasa apologetik-defensif, dalam arti berupaya mempertahankan ideologinya (Sunni) dari kritisisme secara berlebihan.

Dari sudut pandang yang lebih objektif, dalam meneliti konsep tentang Nabi terakhir (khatam al-nabiyyīn) dalam QS. al-Aḥzāb (33): 40 —di mana pemahaman terhadap ayat itu seringkali dijadikan sebagai landasan perdebatan teologis terkait dengan keterputusan atau keberlanjutan wahyu, kenabian dan kerasulan. Lukman Yasin mencoba mengaitkannya dengan konsep imāmah dalam tradisi Syi'ah. Tidak hanya menganalisis berbagai literatur dalam tradisi Syi'ah, Yasin juga membandingkannya dengan berbagai literatur dalam tradisi Sunni. Bahkan untuk memperkuat sisi objektivitasnya, hasil penilitian para orientalis (outsider), seperti Yohanan Friedmann dan Ignaz Goldziher juga ditampilkan. Menurut Yasin, meskipun teologi Syi'ah meyakini bahwa para imām adalah pewaris Nabi SAW yang ma'șüm dan menerima inspirasi (ilham) layaknya para Nabi sebagai sesuatu yang fundamental (origin/thawābit), pada dasarnya tidak ada kata sepakat di kalangan mereka terkait dengan penafsiran frase khatam al-nabiyyīn dalam QS. al-Ahyzab: 40. Kelompok pertama berpandangan bahwa kenabian dan kerasulan memang telah berakhir, meskipun secara problematis mereka tetap menyatakan bahwa 'Ali dan keturunannya memiliki kedudukan dan fungsi yang sama dengan Nabi, sebagai transmitter sekaligus penafsir kehendak Allah. Sementara kelompok kedua nampak berupaya mencari alternatif penafsiran finalitas kenabian, meskipun tidak secara tegas monolak doktrin imāmah. ${ }^{4}$ Penelitian Yasin tergolong bernilai objektif karena sebagai seorang peneliti --meskipun mungkin penganut Sunni, ia mampu menggambarkan perbedaan teologis di antara Sunni dan Syi'ah secara deskriptifempiris, sekaligus mengambil jarak dari objek yang diteliti (outsider). Menempat-

\footnotetext{
4R. Cecep Lukman Yasin, "The Twelver Shi'i Understanding on the Finality of Prophethood" dalam al-Jämi'ah, Vol. 48, No. 1,2010, h. 129-164.
}

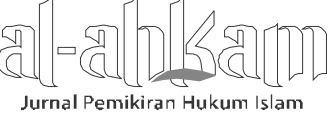


kan diri sebagai outsider dalam hal ini tidak berari bahwa ia keluar dari agama atau aliran teologi yang diikuti, melainkan berupaya untuk tidak terjebak dalam penilaian yang bersifat subjektif.

Lebih jauh, karakter intersubjektivitas nampak pada tulisan Said Agil. Berangkat dari konflik di Sampang (Madura) yang menurut sebagian kalangan berakar pada perbedaan teologis Sunni-Syi'ah, Agil mengatakan bahwa Syi'ah pada awalnya merupakan faksi politik pendukung fanatik 'Ali ibn Abi Ṭālib vis a vis Mu'āwiyah ibn Abī Sufyān. Dalam perjalanannya, Syi'ah kemudian membedakan diri dengan golongan Sunni yang dibangun oleh Abū Hasan al-'Asy'ari dan Abū Manșūr al-Maturidī dalam posisi sebagai aliran teologis. Dalam konteks aliran teologis ini, 'Asy'ari sendiri merupakan eksponen kelompok Mu'tazilah yang belakangan memisahkan diri karena suatu perbedaan berbasis pemikiran teologis. Sampai di sini, Agil berhasil menunjukkan sisi objektivitasnya melalui eksplorasi historisitas perkembangan eksistensi Syi'ah, meskipun tidak berarti bahwa objektivitas tersebut bersifat mutlak (objektifis-cum-subjektifis). Dalam konteks sekarang, perbedaan teologis tersebut merupakan fenomena yang menurutnya tidak seharusnya menjadi alasan terjadinya konflik, disharmoni dan kekerasan.

Menurut Agil, konflik di Sampang sendiri sama sekali tidak berkaitan dengan persoalan teologis. Dalam pada itu, perbedaan teologis internal umat Islam itu tidak tepat jika dipandang harus diselesaikan melalui unifikasi mazhab melainkan harus dipandang sebagai suatu keniscayaan (sunnatullah) yang mengandaikan sikap saling menghormati. Terlebih, prinsip perdamaian, dialog, tidak merasa yang paling benar dan saling menghormati adalah nilai-nilai fundamental yang lebih ditekankan dalam ajaran Islam. ${ }^{5}$ Dalam kesimpulannya tersebut, sesungguhnya Agil menempatkan diri pada posisi intersubjektif, karena berdasarkan penilaiannya ia mampu menempatkan posisi teologis Syi'ah sebagai sesuatu yang bersifat esensial (common pattern) dan harus dihormati. Pemahaman tersebut berimplikasi pada simpati dan empati dalam bertoleransi, hidup berdampingan, menyelesaikan persoalan dan mengatasi berbagai problem yang dihadapi bersama dalam konteks bermasyarakat dan berbangsa.

5Said Agil Siradj, “"The Sunni-Shi'ah Conflict and the Search for Peace in Indonesia” dalam Journal of Indonesian Islam, Vol. 7, No. 1, 2013, h. 146-164. 


\section{Memahami Hadis di Kalangan Sunni-Syi'ah}

Dalam tradisi Sunni, Hadis adalah ucapan, perbuatan, ketetapan dan sifat, atau segala sesuatu yang disandarkan kepada Nabi SAW. Terma Hadis juga identik dengan terma sunnah, khabar dan ațar, meskipun secara teknis memiliki perbedaan dalam penggunaannya. ${ }^{6}$ Berbeda dengan Sunni, dalam tradisi Syi'ah (dalam hal ini Ithnā 'Ash'ariyyah), Hadis atau khabar adalah segala sesuatu yang disandarkan kepada yang ma'șūm, ${ }^{7}$ baik ucapan tindakan dan segala sesuatu yang ditetapkan oleh mereka. Setiap informasi yang tidak disandarkan kepada ma'șūm tidak dapat disebut sebagai Hadis, sehingga informasi yang disandarkan kepada para sahabat atau tabi'in disebut sebagai athar.

Sebagaimana ditulis Hasyim al-Musawi, sepeninggal Nabi SAW, Syi'ah lahir dalam pergumulan panjang pengikut setia 'Ali ra, dan ahl al-bayt. Dalam perkembangannya, golongan ini menjadi sebuah eksistensi politik, intelektual, dan doktrinal yang turut memainkan peran dan pengaruh dalam sejarah peradaban dan kehidupan umat Islam, hingga sekarang. Bagi pengikut Syi'ah, setelah wafatnya Nabi SAW, hujjah keagamaan tidak berhenti, namun secara estafet diteruskan kepada para imām. ${ }^{8}$ Posisi teologis inilah yang kemudian menjadi persoalan kunci dan berimplikasi pada perlakuan mereka terhadap sumber ajaran kedua. Meskipun mengakui sunnah sebagai sumber ajaran kedua, namun sebagai konsekuensi logis dari sentralitas posisi imām, di kalangan Syi'ah Hadis tidak lagi menjadi informasi sejarah yang bersifat statis. Jika dalam tradisi Sunni Hadis menjadi penjelas dan tafsir al-Qur'an, bahkan adakalanya menjadi sumber hukum yang bersifat independen, ${ }^{9}$ sentralitas eksistensi Hadis sebagai informasi sejarah itu terhenti pada sosok Nabi. Berbeda dengan Syi'ah yang memandang sentralitas imām menggantikan fungsi dan tugas Nabi SAW, meskipun bukan dalam posisi kenabian (nubuwwah).

6‘Ajjāj al-Khātị, Ușūl al-Hadīth; 'Ulūmuh wa Muștalāḥuh (Beirut: Dār al-Fikr, 1989), h. 17-27.

${ }^{7}$ Secara berurutan: 'Alī bin Abī Ṭālib (w. 40 H), al-Hasan bin 'Alī bin Abī Tâalib (3-50 H), al-Husayn bin Alī (4-61 H), 'Alī bin Ḥusayn (Zainal 'Âbidīn) (38-94 H), Muhammad bin 'Alī bin Ḥusayn (al-Bāqir) (57-117 H), Ja'far bin Muhammad (al-Ṣādiq) (80-148 H), Mūsă bin Ja'far bin Muhammad (al-Kāzīm) (128-183 H), 'Alī bin Mūsā al-Ridā (148-203 H), Muhammad bin 'Alī al-Jawwād (195-220 H), 'Alī bin Mūsā al-Hādī (214-254 H), al-Hasan bin Mūsā al-'Askarī (232-260 H) dan Muhammad bin al-Hasan al-Mahdī. Hashim al-Musāwī, Mazhab Syiah; Asal-usul dan Keyakinannya terj. Ilyas Hasan (Jakarta: Lentera, 1996), h. 213-214.

8Musawi, MazhabSyiah..., h. 19.

9Jasser Auda, Maqasid al-Shariah as Philosophy of Islamic Law; A System Approach (London: The International Institute of Islamic Thought, 2007), h. 80.

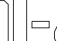

Jurnal Pemikiran Hukum Islam 
Dalam hal ini menjadi wajar jika kitab-kitab kompilasi Hadis yang digunakan Sunni-Syi'ah setelah masa kodifikasi (tadwin) menjadi berbeda.10 Dalam tradisi Sunni, Ṣahīhayn atau Kutub al-Tis'ah: Șaḥịh Bukhārī \& Muslim, Sunan al-Nasā'ī, Abū Dāwud, al-Turmuẓī, Ibn Mājah, al-Dārimī, Muwațta' Mālik dan Musnad Ahmad ibn Hanbal populer menjadi rujukan utama. Sementara Kutub al-Arba'ah: al-Kāfi fi'Ilm al-Dīn yang ditulis oleh Abū Ja'far Muhammad ibn Ya'qūb ibn Isḥāq al-Kulayni arRāzī (w. 328 H/ 939 M), Man Lā Yaḥ̣uruh al-Faqīh karya Abū Ja'far Muhammad ibn 'Alī ibn Babawayh al-Qummī (w. 381 H), Tahdhīb al-Aḥkām fi Sharh al-Muqni' dan al-Istibșār fi mā Ikhtalaf al-Akhbār karya Abū Ja'far Muhammad ibn al-Ḥasan ibn 'Alī ibn al-Ḥasan al-Ṭ̂̄īi (w. 460 H) lebih populer di kalangan Syi'ah.11

\section{Klasifikasi Hadis Sunni-Syi’ah}

Pada dasarnya baik Sunni maupun Syi'ah menggunakan kaidah yang sama untuk menentukan bagaimana sebuah Hadis dapat diterima dan diyakini benar adanya, sehingga layak diterima menjadi landasan sebuah ajaran yang valid. Utamanya dalam kaitanya dengan pemberlakuan dan penetapan hukum. Keduanya mensyaratkan ketersambungan transmisi. Hanya saja karena posisi teologis Syi'ah, eksistensi ketersambungan itu menjadi berbeda. Bagi Sunni, ketersambungan transmisi, berarti sanad itu sampai kepada Nabi SAW. Berbeda dengan Syi'ah yang mensyaratkan ketersambungan itu kepada imām ma'șūm. Keduanya sepakat bahwa Hadis mutawātir dapat diterima dan diyakini sebagai sumber ajaran, di samping mensyaratkan adanya verifikasi ketika Hadis tersebut hanya memiliki kuantitas dalam kategori $a h \bar{a} d$.

Sunni dan Syi'ah juga mensyaratkan bahwa sebuah Hadis atau khabar dapat diterima ketika diriwayatkan oleh periwayat yang 'adil dan akibat dari posisi ideologisnya, keadilan dan kedāaițan seorang periwayat dalam hal ini menjadi tumpang tindih. Dilema ini terjadi seperti ketika seorang periwayat dinilai adil di kalangan Sunni namun tidak demikian di kalangan Syi'ah dan begitu juga sebaliknya.

Dalam tradisi keilmuan Hadis, uraian di atas merupakan kaidah mayor yang menjadi renik ketika diturunkan dalam berbagai kaidah minornya. Namun untuk

\footnotetext{
${ }^{10}$ Tentang sejarah pembukuan (tadwīn) Hadis dalam tradisi Syi'ah, lihat misalnya 'Alī Ahmmad alSālūs, Ma'a al-Ithnā 'Asyariyyah fi al-Ușūl wa I-Furū' (Kairo: Maktabah Dār al-Qur'ān, 2003), h. 671.

11.K.A Howard, "al-Kutub al-Arba'ah; Empat Kitab Hadis Utama Mazhab Ahlul Bait" dalam Jurnal al-Huda; Jurnal Kajian Ilmu-ilmu Islam, Vol. II, No. 4, 2001, h. 10.
}

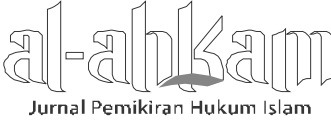


menggambarkan bagaimana beberapa implikasi perbedaan teologis dan ideologis di atas, beberapa elemen penting dalam kaidah mayor dan minor dalam klasifikasi Hadis Sunni dan Syi'ah dipetakan pada: 1) aspek periwayat, dalam arti siapa yang meriwayatkan; 2) aspek kuantitas, dalam arti banyaknya riwayat; dan 3) implikasinya pada aspek penerimaan, dalam arti tipologi riwayat yang dapat dipertimbangkan otentik berdasarkan aspek transmisi.

\section{Transmitter (Periwayat)}

Baik dalam tradisi Sunni maupun Syi'ah, menurut sumber periwayatanya, dikenal penyebutan Hadis marfü', mawqūf dan maqtü'. Disebut sebagai Hadis mar$f u u^{\prime}$, karena informasi di dalamnya memuat ucapan dan perbuatan yang disandarkan kepada Nabi SAW. Begitu juga dengan Hadis mauqūf yang disandarkan kepada para sahabat dan maqțū' yang disandarkan kepada tābi'în, baik dengan ketersambungan maupun terputusnya tranmisi. ${ }^{12}$ Syi'ah membedakan diri dengan Sunni dalam memandang Hadis mawqūf dan maqțū'. Bagi mereka, Hadis mauqūf dan maqtū' tidak dapat diterima dan diyakini, karena tidak berasal dari imām mereka yang mașūm maupun ahl al-bayt. Selain itu, Syi'ah juga menolak pandangan Sunni yang mendefinisikan "șahābah" sebagai orang yang bertemu, mengimani Nabi SAW, dan meninggal sebagai Muslim secara general. Syi'ah membatasi diri pada pengertian bahwa șaḥābah adalah mereka yang benar-benar mempercayai, dekat, mendengarkan dan ikut dalam misi dan aktivitas Nabi SAW.13

\section{Kuantitas Riwayat}

Sebagaimana Sunni, Syi'ah juga memetakan kuantitas Hadis dalam kategori mutawātir. Keduanya menggunakan kategorisasi dan istilah teknis yang sama untuk menyebut informasi yang diriwayatkan oleh banyak rawi, dan secara umum dinilai tidak terdapat kemungkinan konspirasi untuk berdusta. Pada keduanya juga terjadi perbedaan pendapat tentang jumlah atau banyaknya periwayat: empat, sembilan, sepuluh, sebelas, dua puluh, empat puluh, tujuh puluh, sehingga memenuhi kuorum kategori Hadis mutawātir. Kategori mutawatir ini kemudian

\footnotetext{
${ }^{12}$ Ibn Șalāh. 'Ulūm al-Hadīth tahq̣. Nūr al-Dīn 'Itr (Beirut: Dār al-Fikr, 1986), h. 45-47.

13Ja'far al-Subhānī, Ușūl al-Hadìth wa Ahkāmuh fi 'Ilm al-Dirāyah (Qum: Maktabah al-Tawhīd, 1993), h. 48.
}

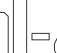

Jurnal Pemikiran Hukum Islam
Volume 24, Nomor 2, Oktober 2014 
dipetakan kembali dalam mutawātir lafụi (satu lafaz dan makna) dan ma'nawī (berbeda lafaz, satu makna); ${ }^{14}$

Dalam tradisi Sunni dikenal penyebutan Hadis mashhür, atau Hadis yang tergolong populer namun belum memenuhi kualifikasi mutawātir.15 Terjadi perbedaan pendapat tentang banyaknya jumlah periwayat. Dalam perkembangannya, pengertian ini dinilai rancu, melihat perbedaan tingkat popularitas sebuah Hadis di kalangan fuqahā' dan ahli Hadis itu sendiri, termasuk pada kelompok yang lain seperti Syi'ah. Di sisi lain, Syi'ah tidak menyebut adanya kategorisasi Hadis masyhur sebagaimana dalam tradisi Sunni.

Mirip dalam tradisi Sunni, di kalangan Syi'ah, khabar atau riwayat yang tidak berada dalam kategori mutawātir, disebut sebagai khabar aḥād atau wāhid. Di kalangan Syi'ah sendiri, pada awalnya penilaian khabar aḥ̄d hanya dipetakan berdasarkan penerimaan atau penolakannya (maqbūl dan mardūd). Dalam perkembangannya, melalui perdebatan yang panjang akhirnya pemetaan tersebut dirumuskan dan dinilai dalam kategori șaḥihh, hasan, muwaththaq dan dẫ̂f, setelah abad ketujuh Hijriyah.

Dalam pengertian khabar aḥ̄̄d ini, jika tidak lebih dari tiga riwayat maka disebut sebagai khabar mustafid. Jika tidak lebih dari dua riwayat disebut khabar 'azīz. Begitu juga dengan khabar yang hanya diriwayatkan oleh satu orang disebut sebagai khabar gharīb. ${ }^{16}$ Sementara dalam tradisi Sunni, Hadis aḥād adalah sebuah riwayat di mana kuantitas periwayatnya tidak memenuhi kuantitas Hadis mutawātir dan mashhūr. Ada juga yang mengkategorikan Hadis ạ̣ād dalam tiga bagian, yaitu Hadis mashhūr (tiga periwayat), 'azīz (dua periwayat) dan gharīb (satu periwayat). ${ }^{17}$

\section{Penerimaan (Maqbūl) atau Penolakan (Mardūd)}

Bagi kalangan Sunni, sebuah Hadis dengan ketersambungan sanad kepada Nabi SAW, tidak memiliki syadh (kejanggalan), 'illah (cacat) dan diriwayatkan oleh orang-orang yang adil serta ḍābiț layak dikategorikan sebagai Hadis șaḥịh.

\footnotetext{
${ }^{14}$ Khațīb, Ușūl al-Hadīth..., h. 301.

15 Ibid, h. 302.

16Sālūs, Ma'a al-Ithnā 'Ashariyyah..., h. 703.

17Khațīb, Ușūl al-Hadīth..., h. 302.
} 
Sementara di kalangan Syi'ah, Hadis șahịh hanya berlaku bagi riwayat yang memiliki ketersambungan transmisi kepada para imam yang ma'șūm, meskipun Syi'ah juga mensyaratkan periwayat yang 'adil pada satiap tingkatan sanad sebagaimana Sunni. Keduanya menggunakan pemetaan șậị lidhātih (memenuhi kualifikasi intern) dan lighayrih (kualifikasi ekstern).18 Dalam kategori riwayat yang dinilai șahịh ini, Syi'ah kemudian menggunakan tiga pemetaan yang tidak dimiliki Sunni, yaitu a'lā (direkomendasikan oleh para imam, di samping disepakati berkeduduan șạīh berdasarkan kaidah yang berlaku), awsat (mutlak disepakati berkedudukan șaḥị̣ dan adnā (șaḥịh berdasarkan ijtihad). ${ }^{19}$

Dalam tradisi Sunni, Hadis hasan adalah sebuah Hadis yang sanadnya bersambung, tidak rancu atau memiliki cacat, serta diriwayatkan oleh periwayat yang adil. Hanya saja terdapat eksepsi yang menjadikan riwayat tersebut hanya menduduki peringkat hasan, seperti ketika sang periwayat dinilai rendah daya hafalnya. Sebagaimana Hadis șạịh, dalam kategori ini juga dikenal pemetaan hasan lidhātih dan lighayrih. ${ }^{20}$ Berbeda dengan kategorisasi Sunni, Syi'ah mendefinisikan Hadis hasan sebagai Hadis yang transmisinya bersambung kepada para imam, namun kethiqahan periwayatnya tidak terjadi pada semua tingkatan. Sementara sebuah Hadis yang diriwayatkan oleh seseorang yang bukan dari kalangan Syi'ah disebut sebagai Hadis muwaththaq. Hadis tersebut dinilai qawiy (kuat), berikut periwayat yang thiqah, namun 'aqidahnya fasād (rusak, bukan Syi'ah). ${ }^{21}$

Di kalangan Sunni dan Syi'ah, sebuah Hadis yang tidak memenuhi kualifikasi

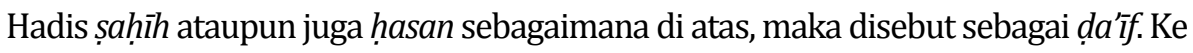
ḍ'îf an sebuah Hadis terjadi karena banyak faktor, seperti: akibat terputusnya sanad di antara periwayat atau terdeteksinya periwayat yang tidak dikenal. Keduanya menilai lemah dan menolak sebuah Hadis, pada umumnya disebabkan oleh standar prosedur operasional, yaitu aspek tidak ketersambungan transmisi, karena mursal (riwayat tabi'in yang dimarfu'kan atau secara langsung disandarkan pada Nabi SAW. bagi Sunni, dan bergeser kepada imām bagi Syi'ah), munqați' (seseorang dalam sebuah sanad yang tidak disebutkan namanya), mu'ḍal (dua

\footnotetext{
${ }^{19}$ Subhānī, Ușūl al-Hadīth..., h. 48.

20 'Itr, Manhajal-Naqd..., h. 264.

21Subhānī, Ușūl al-Hadīth..., h. 48.

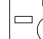

Jurnal Pemikiran Hukum Islam
}

${ }^{18}$ Nūr al-Dīn 'Itr, Manhaj an-Naqd fí 'Ulūm al-Hadīth (Damaskus: Dār al-Fikr, 1981), h. 242. 
rawi gugur secara berurutan dalam sebuah sanad), mudallas (penyamaran dari sisi sanad maupun guru) dan mu'allal (mengandung cacat). Berikut juga beberapa alasan yang lain, seperti muḍa'af (diperdebatkan kuat dan lemahnya), mudțarrib (satu level kualitas namun kontraditif dan berindikasi nāsikh mansūkh), maqlūb (terjadi perubahan dalam sanad maupun matan), matrūk (periwayat dikenal sebagai pendusta, pelupa dan banyak menghayal), mațūh (periwayat yang riwayatnya tidak dihiraukan), maudū' (Hadis palsu atau direkayasa demi kepentingan tertentu) dan sebagainya. ${ }^{22}$

\section{Implikasi Epistemologis dalam Nikah Mut'ah}

Salah satu perbedaan yang menjadi polemik abadi di kalangan Sunni-Syi'ah terkait dengan praktik keagamaan adalah persoalan nikah kontrak (nikah mut'ah). Secara definitif, nikah mut'ah adalah sebuah akad pernikahan dengan perjanjian biaya dan batas waktu yang ditentukan. Meskipun secara teoritis menggunakan kaidah juridis yang sama, dalam arti keduanya sepakat menempatkan al-Qur'an dan sunnah sebagai sumber ajaran tertinggi, ${ }^{23}$ namun pada realitas praksisnya justru menghasilkan produk hukum yang berbeda. Bahkan saling kontradiktif, di mana Sunni mengharamkan dan Syi'ah memperbolehkan. ${ }^{24}$

Keduanya sepakat bahwa nikah mut'ah memang pernah terjadi dan dilegalkan pada masa Nabi. Syi'ah bahkan berpendapat bahwa legalitas nikah mut'ah dijamin dalam QS. al-Nisā': 24, di mana dalam pandangan Sunni, ketentuan ayat itu kemudian dihapus oleh QS. al-Mu'minun: 5-6, al-Ṭalāq: 4 dan al-Nisā': 3. Sementara dalam bantahannya, Syi'ah menyatakan bahwa QS. al-Mu'minūn turun di Makkah jauh sebelum turunnya QS. al-Nisā’ dan tidak mungkin diwahyukan untuk menghapus ketentuan hukum (naskh) pada ayat yang datang sesudahnya. 25

Layaknya efek domino, perdebatan tersebut mengalir pada ekspektasi mengungkap informasi sejarah secara objektif tentang bagaimana sesungguhnya nikah

\footnotetext{
22'Itr, Manhajal-Naqd..., h. 286.

${ }^{23}$ Fakhr al-Dīn Muhammad bin 'Umar bin al-Husayn al-Rāzī, al-Mahșūl fí 'Ilm Ușūl al-Fiqh tahq. Jābir Fayyād\} al-'Alwānī (Beirut: Mu'assasah al-Risālah, t.th.), jilid. 1, h. 385-418. Lihat juga Auda, Maqāṣid al-Shariah..., h. 132-134.

${ }^{24}$ Shahla Haeri, Law of Desire; Temporary Marriage in Shi'i Iran (New York: Syracuse University Press, 1989), h. 51-64. Terjemah dalah bahasa Arab Lihat Shahlā Hāirīī, al-Mut'ah; al-Zuwāj alMu'aqqat 'ind I-Shīah Hālat İrān 1978-1982 terj. Fādī Hamūd (Beirut: Shirkah al-Maṭū'āt li I-Tawzì' wa I-Nashr, 1996), h. 82-95.
}

${ }^{25}$ Haeri, Law of Desire..., h. 61. 
mut'ah pada masa Nabi SAW. Pada poin inilah perdebatan semakin meruncing, utamanya berbasis penggunaan informasi Hadis sebagaimana pembicaraan epistemologi Hadis. Berikut ini beberapa Hadis yang menjadi legitimasi terhadap masing-masing kesimpulan hukum atas larangan dan diperbolehkannya nikah mut'ah.

\section{Nikah Mut’ah PerspektifSunni}

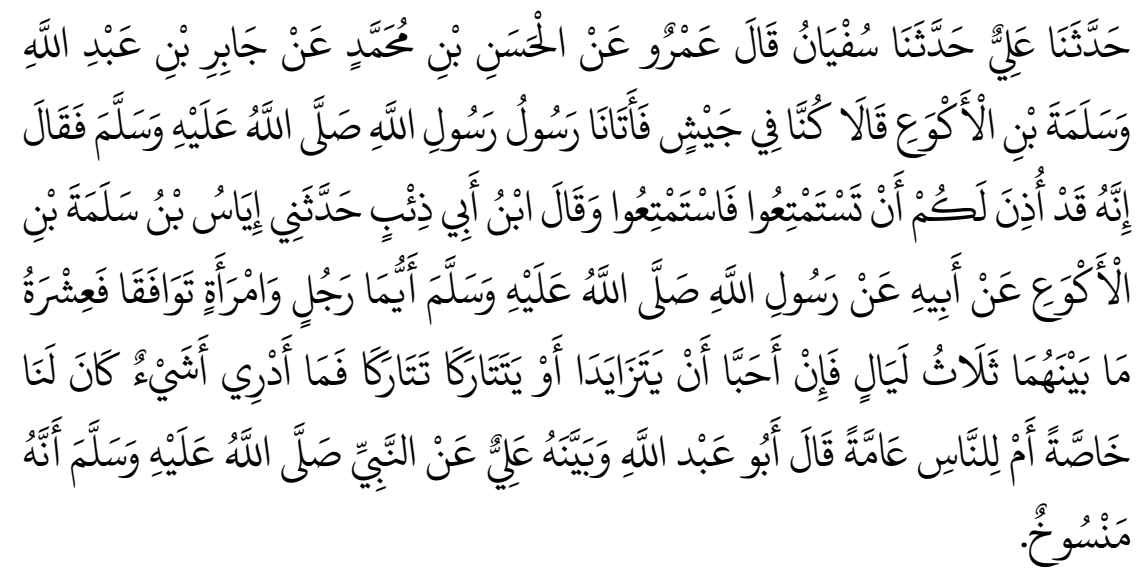

'Ali telah menceritakan kepada kami, bahwa Sufyan telah menceritakan kepada kami, bahwa 'Amr berkata: Dari al-Hasan ibn Muhammad dari Jābir ibn 'Abdillah dan Salamah ibn al-Awka', mereka berdua berkata: Kami berada di lembah Jaysy, Rasulullah SAW, mendatangi kami dan berkata: "Diizinkan kepada kalian untuk bermut'ah, maka bermut'ahlah.” Ibn Abī Dhi'b berkata: "Iyās ibn Salamah ibn al-Awka' telah menceritakan kepada kami dari bapaknya, dari Rasulullah SAW: "Wahai para laki-laki dan perempuan bersepakatlah, bergaullah diantara kalian tiga malam, jika kalian saling menyukai maka lanjutkan atau kalian dapat saling meninggalkan. Aku tidak tahu apakah hal itu hanya bagi kita atau manusia pada umumnya." Abū 'Abdullah berkata: 'Ali menjelaskan dari Nabi SAW, bahwa hal itu telah dihapus."26

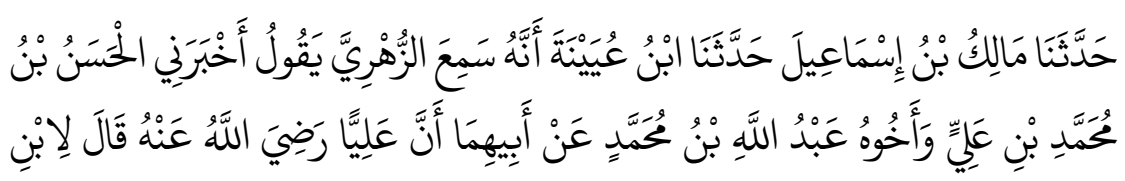

${ }^{26 I b n ~ H ̣ a j a r ~ a l-' A s q a l a ̄ n i ̄, ~ F a t h ̣ ~ a l-B a ̄ r i ̄ ~ b i ~ S h a r h ~ S ̣ a h i ̄ h ̣ ~ a l-B u k h a ̄ r i ̄, ~ t a h q . ~ ' A b d u l ~ Q a ̄ d i r ~ S h a i b a h ~}$ (Madinah: Maktabah al-Mulk, 2001), jilid 9, h. 71.

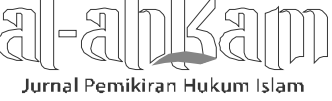




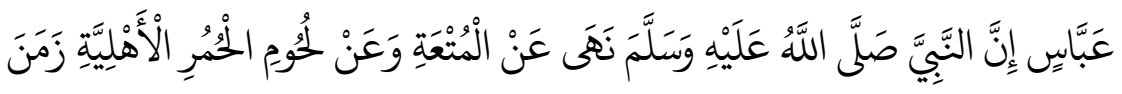

Telah menceritakan kepada kami Mālik ibn Ismāîl, menceritakan kepada kami ibn 'Uyainah bahwa ia mendengar al-Zuhrī berkata: "Telah mengabarkan kepadaku al-Hasan ibn Muhammad ibn 'Alī dan saudaranya 'Abdullah ibn Muhammad dari ayah mereka, bahwa sesungguhnya 'Alī ra, berkata kepada ibn 'Abbās: "Bahwa Nabi SAW, melarang mut'ah dan daging keledai peliharaan pada perang Khaibar."27

Sebagaimana terlihat pada dua riwayat dalam Șạ̣ị̣ al-Bukhārī di atas, pada awalnya nikah mut'ah pernah diperbolehkan, hingga kemudian dilarang oleh Nabi SAW. Melihat teks pertama, dalam transmisi sanad terlihat nama al-Hasan ibn Muhammad (al-Hasan putra 'Ali ibn Abi Ṭālib). Begitu juga dengan teks kedua di mana Hasan juga meriwayatkan bahwa 'Ali ibn Abi Țālib pernah mengatakan kepada Ibn 'Abbās, bahwa nikah mut'ah dilarang oleh Nabi SAW, pasca perang Khaibar. Lepas dari bagaimana otentisitas Hadis tersebut, yang menarik adalah bahwa kedua teks tersebut tidak ditemukan dalam literatur Hadis kompilasi Syi'ah.

\section{Nikah Mutah PerspektifSyi'ah}

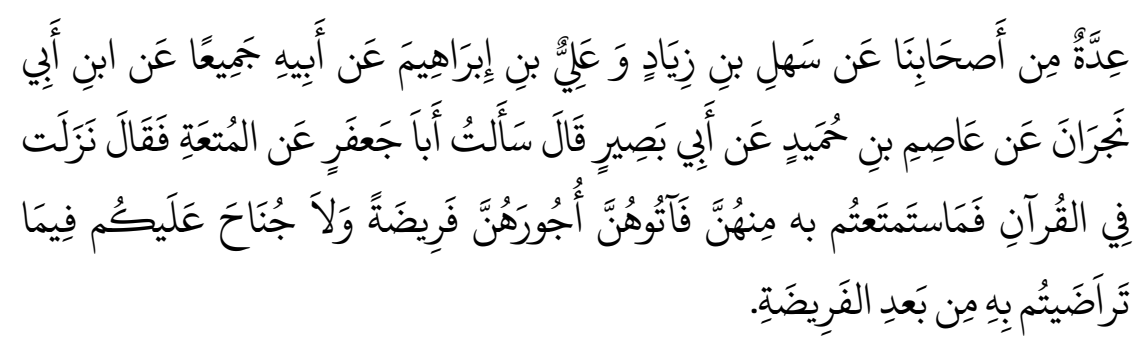

Sejumlah sahabat kami, dari Sahl ibn Ziyād dan 'Alī ibn Ibrāhīm dari bapaknya dari ibn Abī Najrān dari 'Āṣim ibn Ḥumayd dari Bașīr berkata: "Aku bertanya kepada Abū Ja'far tentang mut'ah, ia berkata bahwa telah turun QS. al-Nisā': 24 (Maka isteri-isteri yang telah kamu nikmati (campuri) di antara mereka, berikanlah kepada mereka maharnya (dengan sempurna), sebagai suatu kewajiban; dan tiadalah mengapa bagi kamu terhadap sesuatu yang kamu telah saling merelakannya, sesudah menentukan mahar)."28

\footnotetext{
27'Asqalānī, Fatḥ al-Bārī.., h. 72.

${ }^{28} \mathrm{Abū}$ Ja'far Muhammad bin Ya'qūb al-Kulaynī, al-Furū' min al-Kāfi, taḥq. 'Alī Akbar al-Ghiffārī (Iran: Mu'assasah Anșāriyyah, 2005), h. 1387.
}

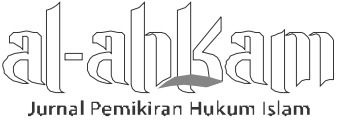




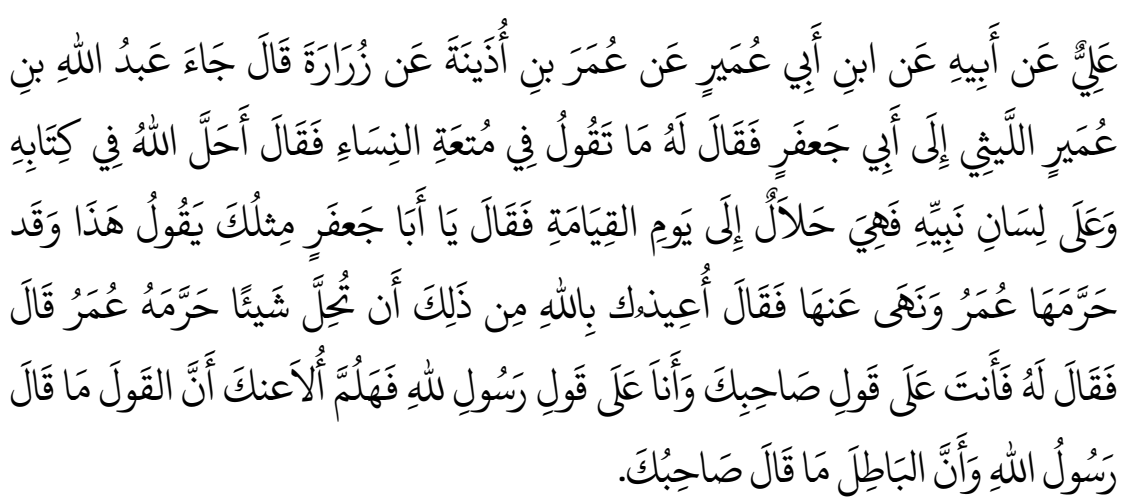

'Alī dari bapaknya dari ibn Abī 'Umayr dari Umar ibn Udhainah dari Zurārah berkata: "Abdullah ibn 'Umair al-Laythī datang kepada Abū Ja'far dan berkata kepadanya": "Apa yang engkau katakan tentang mut’ah," Abū Ja'far berkata: "Allah menghalalkannya dalam Kitab dan melalui lisan Nabi-Nya, mut'ah halal hingga hari kiamat." Ibn 'Umayr berkata: "Wahai Abū Ja'far, sepertimu berkata tentang hal ini, 'Umar telah mengharamkan dan melarang hal itu (mut'ah)." Abū Ja'far berkata: "Aku melindungimu dengan nama Allah atas yang diharamkan 'Umar. Engkau atas ucapan sahabatmu, dan aku atas ucapan Rasulullah SAW, maka seterusnya aku memutuskan kepadamu bahwa kebenaran adalah yang diucapkan Rasulullah SAW, dan yang batil adalah ucapan sahabatmu."29

Khabar dalam al-Furü' min al-Käfı̈ milik al-Kulaynī sebagaimana dikutip di atas menjadikan QS. al-Nisā': 24 sebagai dasar diperbolehkannya nikah mut'ah. Lepas dari otentisitasnya, nampak bahwa tidak ada teks (khabar) yang menunjukkan adanya pembatalan nikah mut'ah sebagaimana dalam tradisi Sunni.

\section{Intersubjektivitas Nikah Mut’ah}

Sebagaimana terlihat, informasi sejarah tentang mut'ah dalam kitab kompilasi Hadis masing-masing kelompok tersebut saling kontradiktif. Informasi sejarah yang dimiliki Sunni menyatakan bahwa pada akhirnya mut'ah telah dilarang. Sementara berdasarkan informasi sejarah yang diyakini Syi'ah, tidak ditemukan adanya pembatalan.

Dalam upaya mengatasi dilema tersebut, para ilmuwan Hadis atau ușūl al-fiqh pada umumnya akan menggunakan beberapa kaidah standar untuk menyelesaikan kontradisi tersebut, di antaranya melalui sintesa (al-jam' wa 'l-tawfiq), meng-

\footnotetext{
${ }^{29}$ Kulaynī, al-Furū'min al-Käfi..., h. 1388.
}

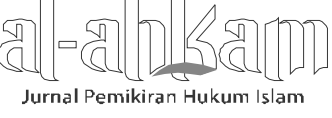


unggulkan yang dianggap paling otentik (tarjīh), atau menganggap salah satu di informasi atau ketentuan hukum telah digantikan dengan informasi atau ketentuan hukum yang lain (naskh). Opsi naskh sendiri telah digunakan oleh kelompok Sunni, di mana dalam berbagai riwayat 'Umar ibn al-Khatțāb diinformasikan telah melarang mut'ah. Namun sebagaimana diurai, Syi'ah tentu tidak akan memandang 'Umar sebagai imām yang ma'șūm sehingga riwayat tersebut jelas tidak akan diikuti oleh kelompok Syi'ah. Tanpa analisis panjang, upaya tarjīh juga akan sulit membuahkan hasil ketika riwayat yang diunggulkan adalah riwayat yang otentik menurut kaidah masing-masing. Sehingga upaya al-jam' wa 'l-tawfiq atau sintesa hanya mungkin terjadi ketika bangunan teologi-ideologis Sunni dan Syi'ah dilepaskan.

Pada kondisi semacam ini, intersubjektivitas dalam fenomenologi agama kemudian memainkan perannya. Bagi Syi'ah dan begitu juga dengan Sunni, pendapat masing-masing mereka tentu mereka yakini benar adanya. Keduanya merasa atau beranggapan bahwa masing-masing mereka telah merepresentasikan Islam yang sesungguhnya (objektif), meskipun pada dasarnya tidak ada jaminan bahwa salah satu di antara keduanya adalah yang paling benar (subjektif). Berdasarkan penelusuran epistemologi Hadis, terungkap suatu struktur fundamental bahwa perbedaan Sunni-Syi'ah dalam memandang Hadis terletak pada perbedaan teologis yang berpengaruh terhadap sumber dan cara masing-masing dalam memandang validitas sebuah Hadis, yang pada hakikatnya merupakan informasi sejarah. Dalam konteks kontemporer, perbedaan mendasar berbasis pemikiran teologis tersebut harus dihormati. Sehingga pada akhirnya kelompok Sunni dan pengikutnya berhak untuk berpendapat bahwa nikah mut'ah merupakan suatu praktik yang tidak diperbolehkan. Begitu juga Syi'ah dan pengikutnya dengan pendapat sebaliknya, tanpa adanya intimidasi.

\section{Kesimpulan}

Hadis adalah informasi sejarah yang meskipun diupayakan untuk digapai secara objektif, secara teoritis tetap menyisakan dimensi subjektivitas. Eksplorasi epistemologi Hadis Sunni-Syi'ah sebagaimana dilakukan dalam kajian ini menunjukkan bahwa aspek teologi menjadi kunci serta sumber utama beberapa perbedaan yang ada. Hal ini terbukti pada rentetan penilaian keduanya terkait dengan diterima atau ditolaknya sebuah transmisi Hadis, meskipun keduanya meyakini bahwa Hadis merupakan sumber ajaran tertinggi setelah al-Qur'an. 
Unifikasi atau upaya penyeragaman nampak sulit dan tidak menjadi solusi bagi perbedaan yang telah mengakar dan mapan dalam berbagai aspeknya. Dalam hal ini, intersubjektivitas menjadi sebuah alternatif solusi dalam memahami haditshadits tentang nikah mut'ah, di mana ketika substansi yang melandasi perbedaan Sunni-Syi'ah dapat ditemukan dalam memandang hukum nikah mut'ah, maka persoalan selanjutnya adalah bagaimana menjadikan perbedaan itu sebagai perbedaan yang saling menguntungkan (mutual-divergence) untuk menghadapi persoalan-persoalan dalam kehidupan berbangsa dan bernegara secara berdampingan.[a]

\section{DAFTAR PUSTAKA}

Amin Abdullah, Islamic Studies di Perguruan Tinggi; Pendekatan IntegratifInterkonektif, Yogyakarta: Pustaka Pelajar, 2006.

al-'Asqalānī, Ibn Ḥajar, al-. Fatḥ al-Bārī bi Sharh Șaḥịh al-Bukhārī taḥq. 'Abdul Qādir Syhaibah. Madinah: Maktabah al-Mulk, 2001.

Auda, Jasser, Maqasid al-Shariah as Philosophy of Islamic Law; A System Approach. London: The International Institute of Islamic Thought, 2007.

Hā'irī, SyahlaShahlā, al-Mut'ah; al-Zuwāj al-Mu'aqqat 'ind 'l-Shyī'ah Hālat İrān 19781982, terj. Fādī ḥamūd,. Beirut: Syhirkah al-Maṭuūāt li 'l-Tauzì' wa 'l-Nashyr, 1996.

Haeri, Shahla, Law of Desire; Temporary Marriage in Shi'i Iran. New York: Syracuse University Press, 1989.

Hauqola, Nur Kholis, “Otentitas Sunnah dan Kedudukannya dalam Legislasi Hukum Islam” dalam Al-Ahkam; Jurnal Pemikiran Hukum Islam, Vol. 24, No. 1, 2014.

Howard, I.K.A. "al-Kutub al-Arba'ah; Empat Kitab Hadis Utama Mazhab Ahlul Bait" dalam Jurnal al-Huda, Jurnal Kajian Ilmu-ilmu Islam, Vol. II, No. 4, 2001.

'Itr, Nūr al-Dīn. Manhaj al-Naqd fi 'Ulūm al-Hadìth, Damaskus: Dār al-Fikr, 1981.

al-Khațīb, 'Ajjāj al-., Ușūl al-Hadìth 'Ulūmuh wa Muștalahuh, Beirut: Dār al-Fikr, 1989.

al-Kulainī, Abū Ja'far Muhammad ibn Ya'qūb, al-. al-Furū' min al-Kāfi, ditaḥqīq 'Alī Akbar al-Ghiffārī. Iran: Mu’assasah Ans\}āriyyān, 2005.

al-Musawi, Hasyim al-. Mazhab Syiah; Asal-usul dan Keyakinannya terj. Ilyas Hasan. Jakarta: Lentera, 1996.

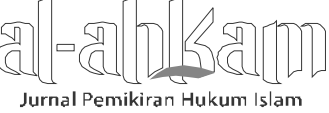


Rahmah, Wahyuni Shifatur. "Epistemologi Hadis dalam Pandangan Sunni dan Syi'ah" dalam Jurnal Studi Ilmu-ilmu al-Qur'an \& Hadis, Vol. 7, No. 2, Juli 2006.

Rasyid, Dawud, "Mawqif Ahl al-Sunnah wa 'l-Syhīah Nạ̣w al-'Itrah alNabawiyyah" dalam Miqot Jurnal Ilmu-ilmu Keislaman, Vol. 37, No. 1, 2013.

al-Rāzī, Fakhr al-Dīn Muḥammad ibn 'Umar ibn al-Husain, al-Maḥs\}ūl fí 'Ilm Ușūl alFiqh, taḥq. Jābir Fayyaḍal-'Alwānī. Beirut: Mu'assasah al-Risālah, t.th.

Șalah, Ibn,. 'Ulūm al-Hadīth, taḥq. Nūr al-Dīn 'Itr. Beirut: Dār al-Fikr, 1986.

al-Sālūs, 'Alī Aḥmad al-., Ma'a 'al-Ithnā 'Ashariyyah fi al-Ușūl wa a'l-Furū'. Mesir: Maktabah Dār al-Qur'ān, 2003.

Siradj, Said Agil, "The Sunni-Shi'ah Conflict and the Search for Peace in Indonesia" dalam Journal of Indonesian Islam, Vol. 7, No. 1, 2013.

al-Subhānī, Ja'far, Ușūl al-Hadīth wa Ahkāmuhu fi 'Ilm al-Dirāyah. Qum: Maktabah al-Tauhīd, 1993.

Yasin, R. Cecep Lukman, "The Twelver Shi'i Understanding on the Finality of Prophethood" dalam al-Jāmi'ah, Vol. 48, No. 1, 2010. 